PEMBELAJAR: Jurnal Ilmu Pendidikan, Keguruan, dan Pembelajaran

Volume 3 Nomor 1 April 2019

e-ISSN: 2549-9114 dan p-ISSN: 2549-9203

(Received: Januari-2019; Reviewed: Maret -2019; Published: April 2019)

DOI : https://doi.org/10.26858/pembelajar.v3i1.6863

\title{
Analisis Kemampuan Menyimak dan Berbicara Anak Melalui Penerapan Metode Bercerita Di Taman Kanak-Kanak (TK) Pertiwi DWP SETDA Prov Sul-Sel
}

\author{
Hajerah \\ Universitas Negeri Makassar, \\ Corresponding e-mail: hajerah@unm.ac.id
}

\begin{abstract}
Abstrak: Tujuan dari penelitian ini adalah untuk (1) penerapan metode bercerita dalam kegiatan pembelajaran di TK Pertiwi DWP SETDA Provinsi Sulawesi Sulatan. (2) Untuk mengetahui kemampuan menyimak dan berbicara pada anak melalui metode bercerita di TK Pertiwi DWP SETDA Provinsi Sulawesi Sulatan. Pendekatan yang digunakan adalah kualitatif kualitatif dengan jenis penelitian deskriptif kualitatif. Fokus penelitian ini yaitu penerapan metode bercerita, kemampuan menyimak dan berbicara anak. Subjek penelitian ini adalah kelompok B3 yang berjumlah 15 orang dan 2 orang guru. Teknik pengumpulan data yang digunakan adalah observasi dan wawancara. Data yang diperoleh melalui instrumen observasi dan wawancara. Kemudian data dianalisis meggunakan analisis deskriptif kualitatif. Hasil penelitian menunjukkan bahwa penerapan metode bercerita pada anak kelompok B1 di TK Pertiwi DWP SETDA Provinsi Sulawesi Sulatan menggunakan metode bercerita dengan menggunakan alat peraga berupa buku cerita, audio visual (TV), boneka tangan, dan gambar berseri, dari ke empat alat peraga tersebut yang paling sering digunakan adalah bercerita dengan menggunakan alat peraga berbentuk audio visual (TV). Berdasarkan hasil penelitian ini maka disarankan kepada semua guru TK untuk menjadikan metode bercerita sebagai salah satu metode pembelajaran dalam mengembangkan kemampuan menyimak dan berbicara anak.
\end{abstract}

Kata kunci: Kemampuan Menyimak, Berbicara, Metode Bercerita

\begin{abstract}
The aims of this research are (1) describe the implementation of storytelling method in learning activity of TK Pertiwi DWP SETDA Provinsi Sulawesi Selatan. (2) to know listening and talking abilities of children in TK Pertiwi DWP SETDA Provinsi Sulawesi Selatan This study was a qualitative with descriptive qualitative model. This study focuses on the application of storytelling method, listening and talking abilities of child. the subject of this research were group B3 which 15 childhood and two teachers. Data collection technique were observation and interview. The analyzed data were using qualitative descriptive analysis. The result of the study showed that the application of storytelling method for B3 group of TK Pertiwi DWP SETDA Provinsi Sulawesi Selatan uses storytelling method by using props in the form of story books, audio visual (TV), hand puppets, and serial images, from the four props are most often used is to tell by using audiovisual (TV). Based on the results of this study was suggested to all kindergarten teachers to make the method of storytelling as one of the learning methods in developing listening and speaking ability of children.
\end{abstract}

Keywords: listening, talking, and storytelling.

(C2019 -Pembelajar Universitas Negeri Makassar. Ini adalah artikel dengan akses terbuka dibawah licenci CC BY-NC-4.0 (https://creativecommons.org/licenses/by-nc/4.0/ ). 


\section{PENDAHULUAN}

Anak usia dini adalah seseorang yang berada pada usia antara nol sampai enam tahun dimana dalam masa tersebut memasuki masa pertumbuhan dan perkembangan (UU No. 20 tahun 2003). Dimana pada masa pertumbuhan dan perkembangannya tersebut mengalami perubahan yang sangat fundamental akan tetapi pada usia selanjutnya anak akan mengalami pertumbuhan dan perkembangan akan tetapi tidak sepesat pada usia nol sampai enam tahun. Pada usia tersebut merupakan yang sangat penting bagi setiap anak sehingga dikatakan dengan istilah usia keemasan atau golden age. Mereka memahami dan belajar dengan cara mereka sendiri, jika dilihat dari sudut pandakng hakikat anak usia dini, maka anak memiliki dua aspek perkembangan yaitu biologis dan psikologis. Pada anak usia dini terjadi perkembangan otak sebagai pusat kecerdasan terjadi sangat pesat. Selain itu, Gesel \& Ames (Hasanah, 2011) menyatakan bahwa pada usia dini organ sensorisnya berkembang sangat pesat, seperti pendengar, penglihatan, penciuman, pengecap, perabaan, dan organ keseimbangan. Menurut Hurlock (1987) bahwa anak usia empat sampai enam tahun merupakan bagian dari anak usia dini yang berada pada rentang usia lahir sampai tahun tahun, dan usia ini secara teminologi disebut sebagai anak usia pra sekolah, dimana pertumbuhan kecerdasannya pada masa ini mengalami peningkatan dari $50 \%$ sampai $80 \%$. Dari beberapa penjelasan tersebut, sehingga disimpulkan bahwa setiap anak memiliki kemampuan yang luar biasa sehingga membutuhkan rangsangan yang tepat berdasarkan karakteristik dan tahap perkembangan anak.

Nugraha (2010) menjelaskan tentang ruang lingkup kurikulum TK dan RA meliputi aspek perkembangan di antaranya yaitu moral dan nilainilai agama, sosial dan emosional, kemandirian, kemampuan berbahasa, kognitif, fisik-motorik, dan seni. Berdasarkan beberapa aspek tersebut, salah satunya dari beberapa aspek yang harus dikembangkan adalah kemampuan Bahasa anak, karena Bahasa mampu mempengaruhi aspek perkembangan lainnya, selain itu bahasa juga merupakan alat dalam berkomunikasi antara satu orang dengan yang lain.
Perkembangan bahasa memiliki empat aspek kemampuan yaitu kemampuan berbicara, kemampuan mendengarkan/menyimak, menulis serta membaca. Dari keempat aspek kemampuan berbahasa tersebut di atas, yang paling sering kita gunakan adalah aspek kemampuan mendengarkan/menyimak atau biasa juga kita kenal istilah bahasa reseptif dan juga kemampuam berbicara atau biasa juga kita kenal dengan istilah bahasa ekspresif. Hal ini dibuktikan oleh Wilga M. River (Sutari, 1997:8) kebanyakan orang dewasa menggunakan $45 \%$ waktunya untuk menyimak, $30 \%$ untuk berbicara, $16 \%$ untuk membaca, dan hanya 9\% saja untuk menulis. Dari penjelasan tersebut sangat jelas bahwa keterampilan menyimak dan berbicara, harus diberikan stimulasi yang tepat sehingga dapat berkembang karena sangat penting di lingkungan pendidikan.

Bahasa reseptif adalah kemampuan yang dimiliki anak berupa kemampuan mendengarkan dan memahami bicara orang lain (Moeslichatoen, 2004:94). Sehingga orang tua dan guru harus mampu menstimulasi kemampuan anak dalam memahami dan mengungkapkan apa yang sebenarnya mereka inginkan, tanpa ada paksaan dari orang lain. Salah satu cara dalam menstimulasi kemampuan bahasa reseptif dan ekspresif anak adalah dengan cara memberikan pendidikan yang sesuai dengan tahap perkembangan dan karakteristik anak.

Secara umum kemampuan berbicara merupakan kemampuan seseorang menyampaikan ide, pikiran, perasaan dengan

menggunakan simbol-simbol bunyi sehingga dapat dipahami oleh orang lain. Menurut Howard (1997: 17) "Sesungguhnya bahasa merupakan ekspresi kemampuan manusia yang sifatnya innate atau bawaan". Perkembangan bahasa pada dasarnya dimulai sejak bayi pertama menangis, sebab tangis bayi dapat dianggap sebagai bahasa anak. Menangis bagi anak merupakan cara mengekspresikan kehendak jiwanya. Dan inilah yang disebut dengan bahasa eksperif dimana tangisan bayi adalah merupakan bahasa dalam mengekpresikan keinginan dan perasaannya.

Dalam penelitian ini, diterapkan langkahlangkah pembelajaran metode bercerita untuk meningkatkan kemampuan menyimak dan berbicara anak di TK Pertiwi DWP SETDA 
Provinsi Sulawesi Sulatan, diharapkan dengan menerapkan metode ini kemampuan menyimak dan berbicara anak di TK tersebut lebih baik lagi.

Berdasarkan pendapat di atas serta mengingat perkembangan kemampuan berbahasa pada anak di TK sangatlah penting sehingga diperlukan pengembangan kemampuan menyimak dan berbicara anak, maka dari itu usaha guru dalam meningkatkan kemampuan berbahasa reseptif anak adalah dengan cara menciptakan suasana belajar yang kondusif sehingga mudah tercipta suasana yang menyenangkan, agar dapat mencapai tujuan dalam proses belajar mengajar tersebut. Maka dari itu peran guru sangat penting dalam memilih metode atau kegiatan yang sesuai dengan tahap perkembangan dan karakteristik tema yang akan kita ajarkan.

Dari sekian banyak metode atau kegiatan yang ada dalam mengembangkan kemampuan menyimak dan berbicara anak, seorang guru bisa memilih salah satunya yaitu dengan cara menerapkan metode bercerita.

Metode bercerita merupakan salah satu kegiatan pembelajaran yang dapat digunakan dalam membantu anak meningkatkan kemampuan bahasanya khususnya kemampuan menyimak dan berbicara anak. Metode bercerita menurut Moeslichatoen (2004: 34) adalah "suatu kegiatan yang dilakukan seseorang secara lisan kepada orang lain dengan alat atau tanpa alat tentang apa yang harus disampaikan dalam bentuk pesan, informasi atau hanya sebuah dongeng, yang dikemas dalam bentuk cerita yang dapat didengarkan dengan rasa menyenangkan". Berdasarkan pendapat tersebut maka peneliti memilih metode bercerita dalam mengembangkan kemampuan menyimak dan berbicara anak, karena di Taman Kanak-kanak metode bercerita adalah salah satu metode yang bisa digunakan dalam mengembangkan bahasa anak. Maka dari itu metode bercerita adalah cara penyampaian atau penyajian materi pembelajaran secara lisan dengan rasa yang menyenangkan dari guru kepada anak.

Oleh karena itu berdasarkan pemaparan di atas, maka penulis ingin meneliti tentang "Analisis Kemampuan Menyimak dan Berbicara Anak melalui Metode Bercerita di Taman Kanakkanak Pertiwi Kota Makassar"

\section{METODE}

Penelitian ini dilakukan dengan menggunakan penelitian deskriptif kualitatif yang bertujuan untuk mengumpulkan data-data tentang kemampuan dalam menyimak serta kemampuan dalam berbicara anak dengan cara bercerita.

Prosedur pelaksaksanaan penelitian ini adalah: (1) menentukan masalah dan tujuan dari penelitian tersebut, (2) menggali kepustakaan seperti konsep, teori dan pandangan dari berbagai pakar, (3) pengambilan sampel penelitian, (4) pengembangan kuesioner, (5) uji coba dan penelitian lapangan, (6) pengolahaan data dan (7) analisis dan laporan hasil penelitian

\section{HASIL DAN PEMBAHASAN}

Pada dasarnya penerapan metode bercerita yang dilakukan dalam kegiatan pembelajaran di TK Pertiwi DWP SETDA Provinsi Sulawesi Sulatan hampir sama dengan metode bercerita yang dilakukan di lembaga-lembaga lain, dimana metode bercerita tersebut terbagi menjadi dua yaitu bercerita membutuhkan alat peraga dan bercerita tanpa memakai alat peraga. Akan tetapi berdasarkan hasil observasi yang dilakukan, ternyata lembaga tersebut lebih senang dan memakai alat peraga ketika bercerita. Adapun langkah-langkah dalam menerapkan metode bercerita dengan memakai alat peraga, antara lain:

Dari observasi pertama yang dilakukan, bentuk pelaksanaan metode bercerita memakai atau memanfaatkan alat peraga berupa buku cerita dengan judul "maling kundang". Kedua dilakukan metode bercerita dengan memakai atau memanfaatkan alat peraga berupa Audio visual (TV) dengan judul "Pesawat Terbang". Ketiga dilakukan dengan metode bercerita memakai atau memanfaatkan alat peraga berupa boneka tangan dengan judul "aku suka makan sayur". Keempat yang dilakukan dengan metode bercerita memakai atau memanfaatkan alat peraga berbentuk audio visual (TV) dengan judul "Putri Salju". Kelima yang dilakukan dengan metode bercerita memakai atau memanfaatkan alat peraga berbentuk Audio Visual (TV) dengan judul "Semangka Emas". Dan observasi keenam yang dilakukan dengan metode bercerita memakai atau memanfaatkan alat peraga berupa buku cerita berseri dengan judul "Ayamku". 
Hasil pengamatan pertama pada hari Senin 27 Maret 2017 dalam hal kemampuan menyimak dan berbicara melalui metode bercerita memakai atau memanfaatkan alat peraga berupa buku cerita dengan judul "maling kundang" adalah:

\section{a. Kemampuan Menyimak Anak}

\begin{tabular}{llllll}
\hline \multirow{2}{*}{ No } & \multicolumn{1}{c}{ Indikator } & \multicolumn{3}{c}{ Kategori } & \multicolumn{2}{c}{ Penilaian Anak } \\
\cline { 2 - 4 } & BB MB & BSH & ah \\
\hline 1 & $\begin{array}{l}\text { Mengerti } \\
\text { beberapa perintah } \\
\text { secara bersamaan }\end{array}$ & 1 & 14 & - & 15 \\
\hline 2 & $\begin{array}{l}\text { Mengulang yang } \\
\text { kalimat } \\
\text { lebih kompleks }\end{array}$ & 2 & 12 & 1 & 15 \\
\hline 3 & $\begin{array}{l}\text { Mengerti aturan } \\
\text { dalam bercerita }\end{array}$ & 1 & 13 & 1 & 15 \\
\hline 4 & $\begin{array}{l}\text { Senang } \\
\text { menghargai } \\
\text { bacaan }\end{array}$ & 5 & 10 & - & 15 \\
\hline
\end{tabular}

\section{b. Kemampuan Berbicara Anak}

\begin{tabular}{|c|c|c|c|c|c|}
\hline \multirow[t]{2}{*}{ No } & \multirow[t]{2}{*}{ Indikator } & \multicolumn{3}{|c|}{$\begin{array}{c}\text { Kategori } \\
\text { Penilaian Anak }\end{array}$} & \multirow{2}{*}{$\begin{array}{c}\text { Juml } \\
\text { ah }\end{array}$} \\
\hline & & $\overline{\mathrm{BB}}$ & MB & $\overline{\mathrm{BSH}}$ & \\
\hline 1 & $\begin{array}{l}\text { Menjawab } \\
\text { pertanyaan yang } \\
\text { lebih kompleks }\end{array}$ & 4 & 11 & - & 15 \\
\hline 2 & $\begin{array}{l}\text { Menyebutkan } \\
\text { kelompok gambar } \\
\text { yang memiliki } \\
\text { bunyi yang sama }\end{array}$ & 5 & 10 & - & 15 \\
\hline 3 & $\begin{array}{l}\text { Menyusun } \\
\text { kalimat sederhana } \\
\text { dalam struktur } \\
\text { lengkap (pokok } \\
\text { kalimat-predikat- } \\
\text { keterangan) }\end{array}$ & 10 & 5 & - & 15 \\
\hline 4 & $\begin{array}{l}\text { Memiliki lebih } \\
\text { banyak kata-kata } \\
\text { untuk } \\
\text { mengekspresikan } \\
\text { ide pada orang } \\
\text { lain }\end{array}$ & 9 & 6 & - & 15 \\
\hline 5 & $\begin{array}{l}\text { Melanjutkan } \\
\text { sebagian } \\
\text { cerita/dongeng } \\
\text { yang telah } \\
\text { diperdengarkan }\end{array}$ & 7 & 8 & - & 15 \\
\hline
\end{tabular}

\begin{tabular}{llllll}
\hline 6 & $\begin{array}{l}\text { Menunjukkan } \\
\text { pemahaman } \\
\text { konsep-konsep } \\
\text { dalam buku cerita }\end{array}$ & 10 & 5 & - & 15 \\
\hline
\end{tabular}

Hasil pengamatan kedua pada hari Senin 17 Maret 2017 dalam hal kemampuan menyimak dan berbicara melalui metode bercerita memakai atau memanfaatkan alat peraga berupa Audio visual (TV) dengan judul "Pesawat Terbang" adalah:

\section{a. Kemampuan Menyimak Anak}

\begin{tabular}{llllll}
\hline \multirow{2}{*}{ No } & \multicolumn{4}{c}{ Indikator } & \multicolumn{3}{c}{ Kategori } & \multirow{2}{*}{ Penilaian Anak } \\
\cline { 2 - 4 } & BB MB & BSH & ah \\
\hline 1 & $\begin{array}{l}\text { Mengerti } \\
\text { beberapa perintah } \\
\text { secara bersamaan }\end{array}$ & - & 15 & - & 15 \\
\hline 2 & $\begin{array}{l}\text { Mengulang } \\
\text { kalimat yang } \\
\text { lebih kompleks }\end{array}$ & 2 & 12 & 1 & 15 \\
\hline 3 & $\begin{array}{l}\text { Mengerti aturan } \\
\text { dalam bercerita }\end{array}$ & 1 & 12 & 2 & 15 \\
\hline 4 & $\begin{array}{l}\text { Senang } \\
\text { menghargai } \\
\text { bacaan }\end{array}$ & 3 & 12 & - & 15 \\
\hline
\end{tabular}

\section{b. Kemampuan Berbicara Anak}

\begin{tabular}{|c|c|c|c|c|c|}
\hline \multirow[t]{2}{*}{ No } & \multirow[t]{2}{*}{ Indikator } & \multicolumn{3}{|c|}{$\begin{array}{c}\text { Kategori } \\
\text { Penilaian Anak }\end{array}$} & \multirow{2}{*}{$\begin{array}{c}\text { Juml } \\
-\quad \text { ah }\end{array}$} \\
\hline & & BB & MB & $\mathrm{BSH}$ & \\
\hline 1 & $\begin{array}{l}\text { Menjawab } \\
\text { pertanyaan yang } \\
\text { lebih kompleks }\end{array}$ & 2 & 13 & - & 15 \\
\hline 2 & $\begin{array}{l}\text { Menyebutkan } \\
\text { kelompok gambar } \\
\text { yang memiliki } \\
\text { bunyi yang sama }\end{array}$ & 3 & 12 & - & 15 \\
\hline 3 & \begin{tabular}{l}
\multicolumn{2}{l}{ Menyusun } \\
kalimat sederhana \\
dalam struktur \\
lengkap (pokok \\
kalimat-predikat- \\
keterangan) \\
\end{tabular} & 6 & 9 & - & 15 \\
\hline 4 & $\begin{array}{l}\text { Memiliki lebih } \\
\text { banyak kata-kata } \\
\text { untuk } \\
\text { mengekspresikan } \\
\text { ide pada orang } \\
\text { lain }\end{array}$ & 7 & 8 & - & 15 \\
\hline
\end{tabular}




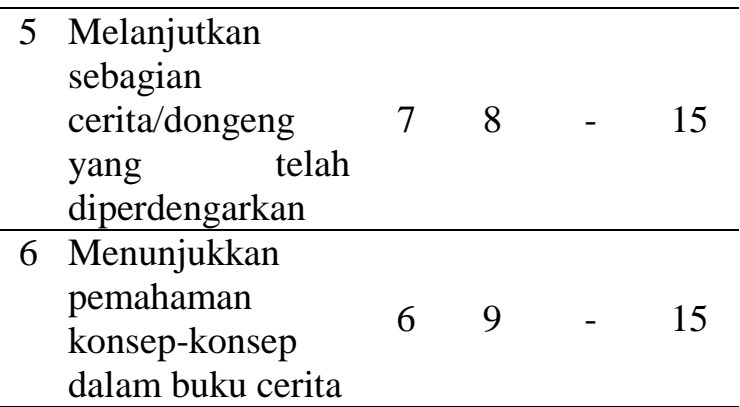

Hasil pengamatan ketiga pada hari Senin tanggal 03 September 2017 berkaitan dengan kemampuan menyimak dan berbicara melalui metode bercerita dengan memakai atau memanfaatkan alat peraga berupa boneka tangan dengan judul "aku suka makan sayur", adalah:

\section{a. Kemampuan Menyimak Anak}

\begin{tabular}{llllll}
\hline \multirow{2}{*}{ No } & \multicolumn{1}{c}{ Indikator } & \multicolumn{3}{c}{ Kategori } & \multirow{2}{*}{ Penilaian Anak } \\
\cline { 2 - 4 } & BB MB & BSH & ah \\
\hline 1 & $\begin{array}{l}\text { Mengerti } \\
\text { beberapa perintah } \\
\text { secara bersamaan }\end{array}$ & - & 12 & 3 & 15 \\
\hline 2 & $\begin{array}{l}\text { Mengulang yang } \\
\text { kalimat } \\
\text { lebih kompleks }\end{array}$ & 2 & 12 & 1 & 15 \\
\hline 3 & $\begin{array}{l}\text { Mengerti aturan } \\
\text { dalam bercerita }\end{array}$ & - & 10 & 5 & 15 \\
\hline 4 & $\begin{array}{l}\text { Senang } \\
\text { menghargai } \\
\text { bacaan }\end{array}$ & - & 15 & - & 15 \\
\hline
\end{tabular}

b. Kemampuan Berbicara Anak

\begin{tabular}{|c|c|c|c|c|c|}
\hline \multirow[t]{2}{*}{ No } & \multirow[t]{2}{*}{ Indikator } & \multicolumn{3}{|c|}{$\begin{array}{c}\text { Kategori } \\
\text { Penilaian Anak }\end{array}$} & \multirow{2}{*}{$\begin{array}{c}\text { Juml } \\
\text { ah }\end{array}$} \\
\hline & & BB & MB & BSH & \\
\hline 1 & $\begin{array}{l}\text { Menjawab } \\
\text { pertanyaan yang } \\
\text { lebih kompleks }\end{array}$ & - & 10 & 5 & 15 \\
\hline 2 & $\begin{array}{l}\text { Menyebutkan } \\
\text { kelompok gambar } \\
\text { yang memiliki } \\
\text { bunyi yang sama }\end{array}$ & - & 8 & 7 & 15 \\
\hline 3 & \begin{tabular}{l}
\multicolumn{2}{l}{ Menyusun } \\
kalimat sederhana \\
dalam struktur \\
lengkap (pokok \\
kalimat-predikat- \\
keterangan)
\end{tabular} & - & 15 & - & 15 \\
\hline
\end{tabular}

\begin{tabular}{|c|c|c|c|c|c|}
\hline 4 & $\begin{array}{l}\text { Memiliki lebih } \\
\text { banyak kata-kata } \\
\text { untuk } \\
\text { mengekspresikan } \\
\text { ide pada orang } \\
\text { lain }\end{array}$ & - & 11 & 4 & 15 \\
\hline 5 & $\begin{array}{l}\text { Melanjutkan } \\
\text { sebagian telah } \\
\text { cerita/dongeng } \\
\text { yang tiperdengarkan }\end{array}$ & - & 15 & - & 15 \\
\hline 6 & $\begin{array}{l}\text { Menunjukkan } \\
\text { pemahaman } \\
\text { konsep-konsep } \\
\text { dalam buku cerita }\end{array}$ & - & 12 & 3 & 15 \\
\hline
\end{tabular}

Hasil pengamatan keempat pada hari Senin tanggal 18 September 2017 berkaitan dengan kemampuan menyimak dan berbicara melalui metode bercerita dengan memakai atau memanfaatkan alat peraga berbentuk audio visual (TV) dengan judul "Putri Salju" adalah:

\section{a. Kemampuan Menyimak Anak}

\begin{tabular}{llllll}
\hline \multirow{2}{*}{ No } & \multicolumn{1}{c}{ Indikator } & \multicolumn{3}{c}{ Kategori } & \multicolumn{2}{c}{ Penilaian Anak } \\
\cline { 2 - 4 } & BB & MB & BSH & ah \\
\hline 1 & $\begin{array}{l}\text { Mengerti } \\
\text { beberapa perintah } \\
\text { secara bersamaan }\end{array}$ & - & 11 & 4 & 15 \\
\hline 2 & $\begin{array}{l}\text { Mengulang } \\
\text { kalimat yang } \\
\text { lebih kompleks }\end{array}$ & - & 14 & 1 & 15 \\
\hline 3 & $\begin{array}{l}\text { Mengerti aturan } \\
\text { dalam bercerita }\end{array}$ & - & 10 & 5 & 15 \\
\hline 4 & $\begin{array}{l}\text { Senang } \\
\text { menghargai } \\
\text { bacaan }\end{array}$ & - & 15 & - & 15 \\
\hline
\end{tabular}

\section{b. Kemampuan Berbicara Anak}

\begin{tabular}{llllll}
\hline \multirow{2}{*}{ No } & Indikator & \multicolumn{3}{c}{ Kategori } & \multicolumn{2}{c}{ Penilaian Anak } & Juml \\
\cline { 2 - 4 } & BB & MB & BSH & ah \\
\hline 1 & $\begin{array}{l}\text { Menjawab } \\
\text { pertanyaan yang } \\
\text { lebih kompleks }\end{array}$ & - & 7 & 8 & 15 \\
\hline 2 & $\begin{array}{l}\text { Menyebutkan } \\
\text { kelompok gambar } \\
\text { yang memiliki } \\
\text { bunyi yang sama }\end{array}$ & - & 8 & 7 & 15 \\
\hline
\end{tabular}




\begin{tabular}{|c|c|c|c|c|c|}
\hline 3 & \begin{tabular}{l}
\multicolumn{2}{l}{ Menyusun } \\
kalimat \\
dalam sederhana \\
lengkap $\quad$ struktur \\
kalimat-predikat- \\
keterangan) \\
\end{tabular} & - & 10 & - & 15 \\
\hline 4 & $\begin{array}{l}\text { Memiliki lebih } \\
\text { banyak kata-kata } \\
\text { untuk } \\
\text { mengekspresikan } \\
\text { ide pada orang } \\
\text { lain }\end{array}$ & - & 11 & 4 & 15 \\
\hline 5 & $\begin{array}{l}\text { Melanjutkan } \\
\text { sebagian } \\
\text { cerita/dongeng } \\
\text { yang telah } \\
\text { diperdengarkan } \\
\end{array}$ & - & 15 & - & 15 \\
\hline 6 & $\begin{array}{l}\text { Menunjukkan } \\
\text { pemahaman } \\
\text { konsep-konsep } \\
\text { dalam buku cerita }\end{array}$ & - & 12 & 3 & 15 \\
\hline
\end{tabular}

Hasil pengamatan kelima pada hari Senin tanggal 25 September 2017 berkaitan dengan kemampuan menyimak dan berbicara melalui metode bercerita dengan memakai atau memanfaatkan alat peraga berbentuk Audio Visual (TV) dengan judul "Semangka Emas" adalah:

\section{a. Kemampuan Menyimak Anak}

\begin{tabular}{llllll}
\hline \multirow{2}{*}{ No } & \multicolumn{1}{c}{ Indikator } & \multicolumn{3}{c}{ Kategori } & \multicolumn{2}{c}{ Penilaian Anak } \\
\cline { 2 - 4 } & BB & MB & BSH & ah \\
\hline 1 & $\begin{array}{l}\text { Mengerti } \\
\text { beberapa perintah } \\
\text { secara bersamaan }\end{array}$ & - & 9 & 6 & 15 \\
\hline 2 & $\begin{array}{l}\text { Mengulang } \\
\text { kalimat yang } \\
\text { lebih kompleks }\end{array}$ & - & 7 & 8 & 15 \\
\hline 3 & $\begin{array}{l}\text { Mengerti aturan } \\
\text { dalam bercerita }\end{array}$ & - & 10 & 5 & 15 \\
\hline 4 & $\begin{array}{l}\text { Senang } \\
\text { menghargai } \\
\text { bacaan }\end{array}$ & - & 10 & 5 & 15 \\
\hline
\end{tabular}

\section{b. Kemampuan Berbicara Anak}

\begin{tabular}{|c|c|c|c|c|c|}
\hline \multirow[t]{2}{*}{ No } & \multirow[t]{2}{*}{ Indikator } & \multicolumn{3}{|c|}{$\begin{array}{c}\text { Kategori } \\
\text { Penilaian Anak }\end{array}$} & \multirow[t]{2}{*}{$\begin{array}{c}\text { Juml } \\
\text { ah }\end{array}$} \\
\hline & & $\mathrm{BB}$ & MB & $\mathrm{BSH}$ & \\
\hline 1 & $\begin{array}{l}\text { Menjawab } \\
\text { pertanyaan yang } \\
\text { lebih kompleks }\end{array}$ & - & 7 & 8 & 15 \\
\hline 2 & $\begin{array}{l}\text { Menyebutkan } \\
\text { kelompok gambar } \\
\text { yang memiliki } \\
\text { bunyi yang sama }\end{array}$ & - & 8 & 7 & 15 \\
\hline 3 & \begin{tabular}{l}
\multicolumn{2}{l}{ Menyusun } \\
kalimat sederhana \\
dalam struktur \\
lengkap (pokok \\
kalimat-predikat- \\
keterangan)
\end{tabular} & - & 11 & 4 & 15 \\
\hline 4 & $\begin{array}{l}\text { Memiliki lebih } \\
\text { banyak kata-kata } \\
\text { untuk } \\
\text { mengekspresikan } \\
\text { ide pada orang } \\
\text { lain }\end{array}$ & 11 & 4 & - & 15 \\
\hline 5 & $\begin{array}{l}\text { Melanjutkan } \\
\text { sebagian telah } \\
\text { cerita/dongeng } \\
\text { yang tiperdengarkan } \\
\text { dipar tela }\end{array}$ & - & 8 & 7 & 15 \\
\hline 6 & $\begin{array}{l}\text { Menunjukkan } \\
\text { pemahaman } \\
\text { konsep-konsep } \\
\text { dalam buku cerita }\end{array}$ & - & 11 & 4 & 15 \\
\hline
\end{tabular}

Hasil pengamatan keenam pada hari Senin tanggal 09 Oktober 2017 berkaitan dengan kemampuan menyimak dan berbicara melalui metode bercerita dengan memakai atau memanfaatkan alat peraga berupa buku cerita berseri dengan judul "Ayamku" adalah:

\section{a. Kemampuan Menyimak Anak}

\begin{tabular}{|c|c|c|c|c|}
\hline \multirow[t]{2}{*}{ No } & \multirow[t]{2}{*}{ Indikator } & \multicolumn{2}{|c|}{$\begin{array}{c}\text { Kategori } \\
\text { Penilaian Anak }\end{array}$} & \multirow{2}{*}{$\begin{array}{l}\text { Juml } \\
-\quad \text { ah }\end{array}$} \\
\hline & & BB MB & BSH & \\
\hline 1 & $\begin{array}{l}\text { Mengerti } \\
\text { beberapa perintah } \\
\text { secara bersamaan }\end{array}$ & 6 & 9 & 15 \\
\hline 2 & $\begin{array}{l}\text { Mengulang } \\
\text { kalimat yang } \\
\text { lebih kompleks }\end{array}$ & 5 & 10 & 15 \\
\hline
\end{tabular}




\begin{tabular}{|c|c|c|c|c|c|}
\hline 3 & $\begin{array}{l}\text { Mengerti aturan } \\
\text { dalam bercerita }\end{array}$ & - & 5 & 10 & 15 \\
\hline 4 & $\begin{array}{l}\text { Senang } \\
\text { menghargai } \\
\text { bacaan }\end{array}$ & - & 7 & 8 & 15 \\
\hline
\end{tabular}

b. Kemampuan Berbicara Anak

\begin{tabular}{|c|c|c|c|c|c|}
\hline \multirow[t]{2}{*}{ No } & \multirow[t]{2}{*}{ Indikator } & \multicolumn{3}{|c|}{$\begin{array}{c}\text { Kategori } \\
\text { Penilaian Anak }\end{array}$} & \multirow[t]{2}{*}{$\begin{array}{c}\text { Juml } \\
-\quad \mathrm{ah}\end{array}$} \\
\hline & & $\mathrm{BB}$ & MB & BSH & \\
\hline 1 & $\begin{array}{l}\text { Menjawab } \\
\text { pertanyaan yang } \\
\text { lebih kompleks }\end{array}$ & - & 5 & 10 & 15 \\
\hline 2 & $\begin{array}{l}\text { Menyebutkan } \\
\text { kelompok gambar } \\
\text { yang memiliki } \\
\text { bunyi yang sama }\end{array}$ & - & 4 & 11 & 15 \\
\hline 3 & \begin{tabular}{lr}
\multicolumn{2}{l}{ Menyusun } \\
kalimat & sederhana \\
dalam struktur & lengkap (pokok \\
kalimat-predikat- \\
keterangan)
\end{tabular} & - & 7 & 8 & 15 \\
\hline 4 & $\begin{array}{l}\text { Memiliki lebih } \\
\text { banyak kata-kata } \\
\text { untuk } \\
\text { mengekspresikan } \\
\text { ide pada orang } \\
\text { lain }\end{array}$ & - & 6 & 9 & 15 \\
\hline 5 & $\begin{array}{l}\text { Melanjutkan } \\
\text { sebagian telah } \\
\text { cerita/dongeng } \\
\text { yang diperdengarkan } \\
\text { dita }\end{array}$ & - & 5 & 10 & 15 \\
\hline 6 & $\begin{array}{l}\text { Menunjukkan } \\
\text { pemahaman } \\
\text { konsep-konsep } \\
\text { dalam buku cerita }\end{array}$ & - & 9 & 6 & 15 \\
\hline
\end{tabular}

Anak adalah merupakan aset yang paling berharga. Sehingga dibutuhkan perawatan khusus sehingga semua aspek perkembangan anak bisa diasa, karena pada usia tersebut mereka akan mengalami pertumbuhan dan perkembangan yang sangat pesat, khususnya pada perkembangan otaknya yang menjadi pusat kecerdasan. Gesel \& Ames (Hasanah, 2011) menyatakan pada usia dini organ sensoris seperti pendengar, penglihatan, penciuman, pengecap, perabaan, serta organ keseimbangan akan berkembang pesat. Menurut
Hurlock (1987) anak usia empat sampai enam tahun merupakan bagian dari anak usia dini yang berada pada rentang usia lahir sampai tahun tahun, dan usia ini secara teminologi disebut sebagai anak usia pra sekolah, dimana pertumbuhan kecerdasannya pada masa ini mengalami peningkatan dari 50\% sampai $80 \%$.

Berdasarkan penjelasan tersebut dapat disimpulkan bahwa setiap anak memiliki kemampuan yang luar biasa sehingga membutuhkan rangsangan yang tepat berdasarkan karakteristik dan tahap perkembangan anak.

Dari beberapa aspek perkembangan anak. perkembangan bahasa adalah merupakan aspek yang sangat penting untuk dikembangkan karena sebagai makluk sosial anak sangat membutuhkan bahasa, karena dengan bahasa seseorang dapat menyampaikan keinginannya. Dalam proses komunikasi anak terkadang menjadi pendengar atau penyimak begitupun sebaliknya anak juga terkadang sebagai pembicara, maka dari itu kemampuan menyimak dan berbicara anak perlu untuk dikembangkan sejak dini. Maka dari itu dibutuhkan metode mengajar yang tepat karena metode mengajar merupakan cara guru menyampaikan pesan peda anak didiknya. Menurut Soetopo (2005) metode mengajar sangat menentukan keberhasilan belajar peserta didik, karena menggunakan metode mengajar yang tepat dan dilaksanakan secara benar dapat membantu peserta didik memahami materi pelajaran dan mencapai tujuan pembelajaran.

Dari sekian banyak metode pembelajaran digunakan dalam proses pembelajaran di khususnya pada pendidikan anak usia dini, metode bercerita adalah merupakan salah satunya cara yang bisa dijadikan alternatif dalam mengembangkan kemampuan menyimak dan berbicara anak bisa berkembang secara efektif.

Bercerita adalah wadah pembinaan anakanak untuk mengembangkan beberapa aspek khususnya kemampuan menyimak dan berbicara anak di TK Pertiwi DWP SETDA Provinsi Sulawesi Sulatan, dimana dalam proses bercerita, anak harus mendengarkan cerita tersebut dan kemudian mengungkapkan apa-apa yang mereka dengarkan dari isi cerita tersebut.

Menurut musbikin (2010) menjelaskan bahwa untuk mengembangkan aspek bahasa anak usia dini, para orang tua maupun guru bisa 
memanfaatkan media cerita, karena dengan cerita anak-anak akan memperoleh banyak perbendaharaan kata-kata baru serta bisa belajar bagaimana mereka menyusun kalimat dengan benar. Dengan begitu hal tersebut akan semakin merangsang perkembangan bahasa anak semakin baik.

Menurut (Beaty: 2014: 319) menjelaskan bahwa mendengarkan merupakan fungsi penting bagi semua anak. Untuk mendengar apa yang dikatakan, anak-anak harus menyimak yaitu memerhatikan kata-kata itu, anak-anak harus menafsirkan, yaitu memberikan makna bagi katakata. Maka, seseorang harus buar suara dengan jelas, menjadikan menarik dan mengulanginya saat berbicara dan nanti pengulangan kata dan tindakan merupakan kunci penting bagi pembelajaran anak kecil. Sedangkan berbicara adalah suatu kemampuan seseorang dalam menyalurkan ide, pikiran, perasaan dengan menggunakan simbol-simbol bunyi sehingga orang lain dapat dengan mudah memhami dan dpahami. Maka dari itu kemampuan menyimak anak akan berkembang selanjutnya kemampuan anak dalam berbicara akan berkembang juga. Menurut Nuraeni (2002:87) kemampuan berbicara merupakan faktor yang sangat mempengaruhi kemahiran seseorang dalam menyampaikan informasi secara lisan. Sedangkan Menurut Tarigan (1981:3) kemampuan berbicara adalah suatu keterampilan berbahasa yang berkembang pada kehidupan anak, yang hanya didahului oleh keterampilan menyimak, dan pada masa tersebutlah kemampuan berbicara atau berujar dipelajari. Berdasarkan uraian di atas bahwa kemampuan berbicara dan menyimak saling terkait antara satu dengan yang maka dari itu untuk dapat mengembangkan kemampuan anak dalam menyimak dan berbicara, sebaiknya guru dapat menerapkan metode bercerita dengan memakai atau memanfaatkan alat peraga pada proses belajar mengajar di TK Pertiwi DWP SETDA Provinsi Sulawesi Sulatan dikarenakan bercerita dengan memakai atau memanfaatkan alat peraga sangat membantu guru dalam memvisualisasikan apa yang akan guru ceritakan. Sedangkan menurut Madyawati (2016) bahwa alat peraga juga berfungsi dalam memvisualisasikan apa yang telah diceritakan dan dapat membuat pencerita semakin pandai menemukan ide, alat apa yang akan dia gunakan untuk bercerita, sehingga dapat menciptkan suasana menjadi lebih hidup, selain itu bisa juga mendesain suasana setting tempat, contohnya tempat terjadinya peristiwa tersebut.

Berdasarkan hasil observasi dan wawancara yang dilakukan di TK Pertiwi DWP SETDA Provinsi Sulawesi Sulatan bahwa para pendidik lebih memilih metode bercerita memakai atau memanfaatkan alat peraga berupa: buku cerita, audio visual (TV), boneka tangan, dan gambar berseri dari ke empat alat peraga tersebut yang paling sering digunakan adalah bercerita memakai alat peraga berbentuk audio visual (TV).

\section{SIMPULAN DAN SARAN}

Dari hasil penelitian dan pembahasan tersebut, maka kesimpulan dari penelitian ini, adalah:

1. Penerapan metode bercerita pada anak kelompok B3 di TK Pertiwi DWP SETDA Provinsi Sulawesi Sulatan memakai atau memanfaatkan alat peraga berupa buku cerita, Audio visual (TV), boneka tangan dan gambar berseri.

2. Kemampuan menyimak dan berbicara anak mengalami peningkatan pada saat menggunakan metode bercerita memakai atau menggunakan alat peraga seperti buku cerita, Audio visual (TV), boneka tangan dan gambar berseri.

Mengacu kepada kesimpulan di atas, maka disaran kepada:

1. Guru hendaknya berupaya secara optimal menerapkan metode pembelajaran yang sesuai langkah-langkah dalam menggunakan khususnya bercerita dengan memanfaatkan atau memakain alat peraga agar karena dapat mengembangkan berbagai aspek perkembangan bahasa khususnya kemampuan menyimak dan berbicara anak.

2. Menumbuhkan motivasi dalam diri anak untuk mengikuti proses belajar mengajar dengan menerapkan metode bercerita agar kemampuan menyimak dan berbicara anak dapat berkembang lebih optimal. 
Hajerah. Analisis Kemampuan Menyimak dan Berbicara Anak Melalui Penerapan Metode Bercerita Di

\section{DAFTAR PUSTAKA}

Beaty. J. Janice. 2014. Observasi Perkembangan Anak Usia Dini. Jakarta: Kencana.

Hasanah, Uswatun. 2011. Mengembangkan Daya Pikir \& Daya Cipta Anak Usia 5-6 Tahun. Online: (http://paud-uny.blogspot.com/). Diakses 1 Februari 2017.

Hurlock, Elizabeth, B. 1978. Perkembangan Anak. Jilid I. Jakarta: Erlangga

Howard.1997. Pengembangan Bahasa untuk Anak Usia Dini. Jakarta: Rineka Cipta

Musbikin, Imam. 2010. Buku Pintar PAUD dalam Perspektif Islam. Yogyakarta: Laksana.

Madyawati, lilis. 2016. Strategi Pengembangan Bahasa pada Anak. Jakarta: Kencana.

Moeslichatoen. 2004. Metode Pengajaran Di Taman Kanak-kanak. Jakarta: Rineka Cipta.

Nugraha, A. 2010. Kurikulum dan Bahan Belajar TK. Jakarta: Universitas Terbuka.

Nuraeni. 2002. Pembelajaran Bahasa Indonesia SD dan Apresiasi Bahasa dan Sastra Indonesia. Yokyakarta: BPG.

Soetopo, Hendyat. 2005. Pendidikan dan Pembelajaran Teori, permasalahan dan Praktek. Malang: UMM Pres.

Sutari, dkk. 1997. Menyimak. Jakarta: Depdikbud

Tarigan, Henry Guntur. 1981. Menyimak Sebagai Suatu Keterampilan Berbahasa. Bandung: Angkasa.

Undang-undang Nomor 20 Tahun 2003 tentang Sistem Pendidikan Nasional. Jakarta. 